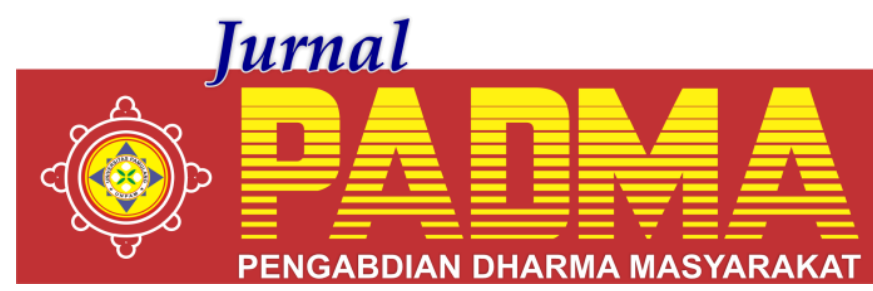

VOLUME 1, NOMOR 2, APRIL 2021

\title{
TAX PLANNING (INSENTIF PAJAK) SEBAGAI STRATEGI UMKM BINAAN KADIN JAWA BARAT DALAM MENGHADAPI DAMPAK COVID-19
}

\author{
${ }^{1 *}$ Neneng Susanti, ${ }^{2}$ Ivan Gumilar Sambas Putra, ${ }^{3}$ Muhammad Bayu Aji Sumantri, ${ }^{4}$ ugi \\ Muhammad Nugraha, ${ }^{5}$ Supardi, ${ }^{6}$ Tanti Irawati Mukhlis, ${ }^{7}$ Vincentia Wahju Widajatun \\ Universitas Widyatama, Bandung, Jawa Barat, Indonesia \\ *neneng.susanti@widyatama.ac.id
}

\begin{abstract}
Abstrak
Kegiatan pengabdian kepada masyarakat diselenggaran dengan tujuan untuk memberikan pemahaman kebijakan pemerintah dalam pemberian insentif pajak; pemahaman atas masa pembayaran, penyetoran dan pelaporan pajak; dan perhitungan atas pph (pajak penghasilan).

Pelaksanaan kegiatan pengabdian kepada masyarakat dilakukan dengan metode ceramah, tutorial, dan diskusi. Materi kegiatan mengenai Tax Planning (insentif pajak) sebagai strategi UMKM dalam menghadapi dampak COVID-19 dengan harapan memberikan pemahaman bagi UMKM yang nantinya dapat diterapkan dan ditularkan ke masyarakat luas. Target materi pada kegiatan penyuluhan PKM tercapai dengan cukup baik, dapat dilihat dari hasil pemahaman dari materi kegiatan. Untuk menerapkan hasil dari kegiatan masih diperlukan UMKM binaan KADIN di sektor kuliner dan fashion dapat melaksanakan pengadministrasian keuangan yang baik, merencanakan strategi keuangan yang baik dan perencanaan perpajakan tepat guna dan tertib administrasi.
\end{abstract}

Kata Kunci : Tax planning, insentif pajak, Covid 19, UMKM

\begin{abstract}
Community service activities are held with the aim of providing an understanding of government policies in providing tax incentives; understanding of the payment period, deposit and tax reporting; and calculation of pph (income tax). The implementation of community service activities is carried out by means of lectures, tutorials, and discussions. Activity material regarding Tax Planning (tax incentives) as a strategy for MSMEs in dealing with the impact of COVID-19 with the hope of providing understanding for MSMEs which can later be applied and transmitted to the wider community. The target material in PKM extension activities was achieved quite well, it can be seen from the results of the understanding of the activity material. To implement the results of these activities, KADIN-assisted MSMEs in the culinary and fashion sectors are still required to carry out good financial administration, plan a good financial strategy and plan taxation in an efficient and orderly manner.
\end{abstract}

Keywords: Tax planning, tax incentives, Covid 19, UMKM.

\section{PENDAHULUAN}

Usaha Kecil Mikro Menengah (UMKM) adalah bisnis yang dijalankan oleh perorangan, keluarga, atau badan usaha kecil. UMKM merupakan agen yang mampu membawa perubahan secara terus-menerus pada masyarakat karena mampu membantu memajukan dan membawa inovasi serta meningkatkan kreativitas (Dhewanto et al:2015). Di Indonesia UMKM memiliki peran startegis dan pengaruh yang besar bagi perkembangan ekonomi Nasional dengan jumlah 64.194.057 pada tahun 2018 dengan memperkerjakan sekitar 116.978.631 tenaga kerja (Hardilawati: 2020).
UMKM binaan Kadin Jabar mulai beroperasi dari tahun 2017. Sector usaha fashion, kuliner merupakan sector dengan jumlah UMKM terbanyak sebesar (52\%), sementara sisanya merupakan sector-sektor kerajinan tangan, bumbu masak, kosmetik, peternakan, pewangi, minuman herbal, dan alat kesehatan.

Ditengah berkembangnya UMKM pada tanggal 2 Maret 2020 untuk pertama kalinya dideteksi COVID-19 di Indonesia, COVID-19 bukan hanya sekedar bencana kesehatan tetapi telah menimbulkan kekacauan di berbagai sektor. Sektor ekonomi tidak ketinggalan, COVID-19 memberikan dampak 
yang sangat signifikan pada perekonomian domestik negara-bangsa dan keberadaan UMKM, UMKM mengalami penurunan pendapatakan kurang lebih mencapai 50\%

Kuncoro dalam (Setyanto:2015) yang menyatakan tentang faktor penghambat perkembangan suatu usaha secara lebih spesifik, yaitu; Pertama, sulitnya mendapatkan peluang pasar dan memperluas pangsa pasar. Kedua, sulitnya mendapatkan modal karena terbatasnya sumber modal yang memadai. Ketiga, kurangnya pemahaman dalam bidang organisasi dan manajemen SDM. Keempat, Kurang luasnya mitra kerjasama antar pengusaha. Kelima, Persaingan yang tidak sehat antar pengusaha. Keenam, Pembinaan dan pelatihan yang dilakukan masih kurang terpadu dan kurangnya kepedulian serta kepercayaan masyarakat terhadap keberadaan usaha kecil.

Covid-19 telah menimbulkan economic shock, yang mempengaruhi ekonomi secara perorangan, rumah tangga, perusahaan mikro, kecil, menengah maupun besar, bahkan mempengaruhi ekonomi negara dengan skala cakupan dari lokal, nasional, dan bahkan global (Taufik:2020).

Social distancing merupakah salah satu upaya yang diterapkan pemerintah dalam mengurangi penyebaran COVID-19, dengan diterapkannya social distancing telah menurukan aktivitas ekonomi dan produktivitas produksi pelaku usaha dimana berakibat pada penurunan penerimaan pajak. Selain itu Covid-19 telah melemahkan nilai tukar rupiah dan menurunkan daya beli masyarakat. Merespon hal tersebut, pemerintah mengambil strategi untuk menjaga eksistensi usaha di beberapa sektor yang terdampak COVID-19 dengan memberikan stimulus ekonomi berupa pemberian insentif pajak.

Diluar kebijakan pajak pemerintah telah mengeluarkan kebijakan untuk memberikan kelonggaran pembayaran cicilan hutang atau kredit bagi UMKM atau bahkan menunda proses pembayaran tersebut sampai enam bulan kedepan dengan mempertimbangkan likuiditas keuangan UMKM. Termasuk juga menyederhanakan proses administrasi mendapatkan pinjaman di tengah situasi darurat ini.
Penerimaan pajak turun sejalan dengan tax expenditure meningkat. Peningkatan tax expenditure akan meningkatkan government expenditure, yang memberikan multiplier effect pada perekonomian nasional, diantaranya adalah peningkatan daya beli masyarakat yang akan meningkatkan PPN, serta stabiltas ekonomi, produktifitas usaha dan manajemen kas yang sehat diharapkan dapat meningkatkan potensi PPh terutang setelah periode insentif berakhir.

\section{METODE}

Metode pelaksanaan pengabdian kepada masyarakat ini diawali dengan melakukan peninjauan lapangan dan koordinasi dengan mitra. Survey awal yang dilakukan oleh tim pengusul untuk mengetahui permasalahan yang dihadapi oleh mitra terkait dampak COVID-19. Pelaksanaan pengabdian kepada masyarakat dilakukan secara daring pada tanggal 25 Februari 2021 melalui google meet. Metode kegiatan pengabdian yang digunakan adalah metode ceramah, tutorial, dan diskusi yang dipilih untuk menyampaikan materi. Pemanfaatan laptop dan Liquid Crystal Display (LCD) membantu peserta pelatihan lebih mudah memahami dan mengingat materi pelatihan relatif banyak dengan waktu pelatihan yang terbatas.

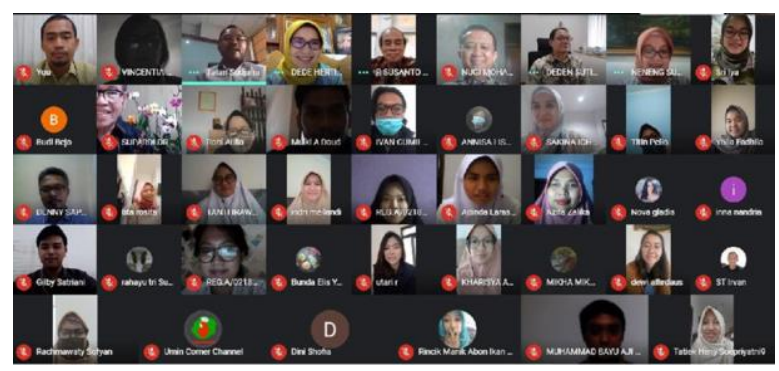

Gambar 1. Pelaksanaan Kegiatan Melalui Google Meet

\section{HASIL DAN PEMBAHASAN}

Berdasarkan data Kementerian Koperasi dan UKM RI, UMKM secara keseluruhan mengalami perkembangan dan pertumbuhan yang baik seiring berganti tahun. Misalnya pada tahun 2010, total jumlah unit UMKM sebanyak 52.769.426. Lalu dalam pemberitaan terakhir, jumlah tersebut sudah mencapai angka 63 juta. 
UMKM memiliki kontribusi yang sangat besar dan krusial bagi perekonomian kita secara makro. Kementerian Koperasi dan UKM RI melaporkan bahwa secara jumlah unit, UMKM memiliki pangsa sekitar $99,99 \%$ (62.9 juta unit) dari total keseluruhan pelaku usaha di Indonesia (2017), sementara usaha besar hanya sebanyak 0,01\% atau sekitar 5400 unit. Usaha Mikro menyerap sekitar 107,2 juta tenaga kerja $(89,2 \%)$, Usaha Kecil 5,7 juta (4,74\%), dan Usaha Menengah 3,73 juta $(3,11 \%)$; sementara Usaha Besar menyerap sekitar 3,58 juta jiwa. Artinya secara gabungan UMKM menyerap sekitar 97\% tenaga kerja nasional, sementara Usaha Besar hanya menyerap sekitar 3\% dari total tenaga kerja nasional!

Sejak pandemi Covid-19 diumumkan, banyak bidang ekonomi domestik dan global telah terpengaruh, dampak pandemi paling menonjol pada sektor usaha mikro, kecil, dan menengah (UMKM). Di berbagai media juga diberitakan bahwa sejak pandemi Covid-19 merebak di Indonesia, para pelaku UMKM mulai menghadapi berbagai kesulitan bisnis, akibatnya UMKM setidaknya mengalami penurunan pendapatan sebesar kurang lebih $50 \%$. Untuk itu, pemerintah mengambil strategi untuk mempertahankan bisnis di berbagai industri yang terkena dampak Covid-19 dengan memberikan stimulus ekonomi dalam bentuk insentif perpajakan.

Pajak merupakan sumber pendapatan nasional terbesar di Indonesia, terhitung 80\%. Dengan proporsi yang begitu besar tersebut, sayangnya sebagian besar pelaku UMKM masih belum memahami perpajakan atau belum pernah memenuhi kewajiban perpajakannya. Peserta usaha kecil, mikro, dan menengah (UMKM) dengan omzet hingga Rp4,8 miliar dikenai tarif 0,5\% yang diberlakukan sejak Juli 2018. Tarif telah diturunkan dari sebelumnya $1 \%$.

Perubahan tarif UMKM ini tertuang dalam Peraturan Pemerintah (PP) Nomor 23 Tahun 2018 tentang Pajak Penghasilan atas Penghasilan Dari Usaha yang Diterima atau Diperoleh Wajib Pajak yang Memiliki Peredaran Bruto Tertentu. Peraturan Pemerintah tersebut menggantikan peraturan yang sebelumnya yaitu Peraturan Pemerintah (PP) Nomor 46 Tahun 2013. Pemerintah menurunkan tarif tersebut dengan tujuan dapat membantu pengembangan usaha para UMKM dan juga untuk menjaga arus kas supaya dapat digunakan sebagai tambahan modal. Jadi tidak ada alasan lagi untuk para pelaku UMKM tidak menjalankan kewajiban perpajakannya. Untuk menjalankan kewajiban perpajakannya dengan baik itu, UMKM harus memiliki terlebih dahulu NPWP. Namun, banyak pelaku UMKM yang menganggap bahwa pendaftaran NPWP itu dirasa sulit dan membutuhkan waktu yang lama, sehingga lebih memilih untuk tidak menjalankan kewajiban perpajakannya daripada berlama-lama di kantor pajak menunggu pendaftarannya selesai diproses. Padahal apabila syarat yang diperlukan sudah dilengkapi dengan baik dan identitas sang pendaftar jelas, maka proses pendaftaran NPWP tidak akan berlangsung lama.

Permasalahan yang sering muncul di loket Tempat Pelayanan Terpadu (TPT) adalah terkadang wajib pajak melakukan registrasi NPWP hanya untuk memenuhi persyaratan bank atau sebagai syarat untuk menerbitkan izin usaha. Dengan cara ini, persyaratan yang diperlukan tidak dapat dipenuhi dengan benar. Hal seperti ini dapat menghambat atau memperpanjang proses pendaftaran NPWP karena wajib pajak harus mengisi formulir terlebih dahulu di loket, dan formulir tersebut harus sudah diisi di loket agar dapat segera diproses.

Persyaratan pendaftaran NPWP (Pengusaha) antara lain fotokopi KTP, fotokopi surat keterangan usaha atau SKU (disebut juga SKU) dinas atau dinas terkait izin usaha, dan fotokopi akta keluarga (wajib apabila yang pendaftar seorang istri) Selain itu, diperlukan juga formulir pernyataan bisnis yang ditandatangani dengan materai Rp. 6000, dan mengisi formulir pendaftaran NPWP yang disediakan oleh biro pajak dan ditandatangani oleh pemohon.

Persyaratan semua dokumen sudah lengkap, pendaftaran NPWP tidak perlu menunggu lama. Bahkan selain langsung ke biro pajak, Anda juga bisa mengisi data diri di laman online melalui https://ereg.pajak.go.id untuk melengkapi registrasi NPWP, namun untuk registrasi NPWP dilakukan. dapat merekomendasikan kami untuk pergi langsung ke Departemen 
Pendapatan Pedalaman. Pendaftaran NPWP telah selesai dilaksanakan, maka kewajiban yang harus dipenuhi oleh wajib pajak usahawan adalah melakukan pembayaran dan pelaporan pajak. Pembayaran dilakukan setiap bulan dengan memperhitungkan omzet yang diperoleh pada bulan yang bersangkutan. Kemudian omzet itu dikalikan dengan tarif $0,5 \%$ untuk omzet yang diperoleh sejak bulan Juli 2018 hingga sekarang.

Pembayaran telah dilakukan, langkah terakhir adalah melaporkan SPT tahunan. Laporan tahunan SPT ini dapat diselesaikan di KPP atau melalui situs online Pajak.go.id. Batas waktu penyampaian SPT tahun ini mulai Januari tahun berikutnya hingga Maret tahun berikutnya. Misalnya, jika ingin melaporkan SPT tahunan tahun pajak 2019, harap laporkan dari Januari 2020 hingga Maret 2020. Dengan kemajuan teknologi yang semakin memudahkan wajib pajak, diharapkan para pelaku UMKM khususnya seluruh pelaku UMKM di Indonesia secara umum dapat memenuhi kewajiban perpajakannya secara tertib.hidupnya.

\section{PENUTUP \\ KESIMPULAN DAN SARAN}

Perkembangan UMKM di Jawa Barat sekaligus Indonesia menunjukkan pola yang baik. Adanya dukungan pemerintah mempengaruhi laju pertumbuhan jumlah usaha mikro, kecil dan menengah dalam beberapa hal. Penggunaan fasilitas teknologi dan komunikasi, penyaluran kredit bank kepada masyarakat, dan penurunan tarif pajak penghasilan final merupakan faktorfaktor yang mendorong perkembangan UMKM Indonesia, dan juga faktor-faktor yang dirumuskan oleh pemerintah Indonesia dalam kebijakan Tax Planning (Insentif pajak). Pemerintah membantu UMKM dalam kegiatan sehari-hari. Meski begitu, karena beberapa faktor pendukung dinilai kurang efektif, pertumbuhannya masih tergolong lambat.

$\begin{array}{ccc}\text { Dengan berita ini, } & \text { UMKM berperan } \\ \text { penting } & \text { dalam } & \text { mempertahankan }\end{array}$ perekonomian nasional. Sektor ini menyumbang lebih dari 60\% PDB (Produk
Domestik Bruto) dan mengurangi pengangguran dengan menyumbang lebih dari 95\% angkatan kerja, namun pandemi COVID-19 telah mengurangi usahanya, sehingga dukungan UMKM diperlukan untuk dapat bertahan hidup. Akibat tekanan ekonomi akibat COVID-19, pemerintah melalui pengawasan Menteri Keuangan memberikan insentif perpajakan kepada wajib pajak yang terkena dampak COVID-19.

\section{DAFTAR PUSTAKA}

Azizah, Fadilah Nur. (2020). Strategi UMKM untuk Meningkatkan Perekonomian selama Pandemi Covid-19 pada saat New Normal. OECONOMICUS Journal of Economics, Vol. 5, (No. 1), Hlm. 4662.

Hardilawati, W. laura. (2020). Strategi Bertahan UMKM di Tengah Pandemi Covid-19. Jurnal Akuntansi Dan Ekonomika, 10(1), 89-98. https://doi.org/10.37859/ jae.v10i1.1934

Effendy, A., \& Sunarsi, D. (2020). Persepsi Mahasiswa Terhadap Kemampuan Dalam Mendirikan UMKM Dan Efektivitas Promosi Melalui Online Di Kota Tangerang Selatan. Jurnal Ilmiah MEA (Manajemen, Ekonomi, \& Akuntansi), 4(3), 702-714. https://doi.org/10.31955/mea.vol4.iss3 .pp702-714

Taufik dan Eka Avianti Ayuningtyas. 2020. Dampak Pandemi Covid-19 Terhadap Bisnis dan Eksistensi Platform Online. Sekolah Tinggi Ilmu Ekonomi IPWI Jakarta p-ISSN 1411-710X e-ISSN 2620-388X

Haque, MG., Munawaroh, Sunarsi, D., (2020). Analysis of SMEs Culinary Marketing Strategy During Covid 19 Pancemic: A Study at "Sate Bebek Cilegon" Resto in Cilegon, Banten. International Journal of Education, Information Technology, and Others. Vol.3. Issue 2

http://www.depkop.go.id/data-umkm, diakses 6 Maret 2021

https://www.ukmindonesia.id/bacaartikel/62, diakses 6 Maret 2021 